\title{
Chevron Has Only One Step
}

\section{Citation}

Matthew Stephenson \& Adrian Vermeule, Chevron Has Only One Step, 95 Va. L. Rev. 597 (2009).

\section{Published Version}

http://www.virginialawreview.org/content/pdfs/95/597.pdf

\section{Permanent link}

http://nrs.harvard.edu/urn-3:HUL.InstRepos:10849722

\section{Terms of Use}

This article was downloaded from Harvard University's DASH repository, and is made available under the terms and conditions applicable to Open Access Policy Articles, as set forth at http:// nrs.harvard.edu/urn-3:HUL.InstRepos:dash.current.terms-of-use\#OAP

\section{Share Your Story}

The Harvard community has made this article openly available.

Please share how this access benefits you. Submit a story.

\section{Accessibility}




\section{ESSAYS}

\section{CHEVRON HAS ONLY ONE STEP*}

\section{Matthew C. Stephenson ${ }^{\dagger}$ and Adrian Vermeule}

[The agency's] view governs if it is a reasonable interpretation of the statute.... [S] urely if Congress has directly spoken to an issue then any agency interpretation contradicting what Congress has said would be unreasonable.

Justice Antonin Scalia's majority opinion in Entergy Corp. v. Riverkeeper, Inc. ${ }^{1}$

C HEVRON U.S.A. v. Natural Resources Defense Council lays out a two-step process that courts must follow when they review a federal agency's construction of a federal statute. ${ }^{2}$ Despite the prominence of this two-step framework, we will argue that Chevron, properly understood, has only one step. ${ }^{3}$ Chevron's artificial division of one inquiry into

\footnotetext{
*We are grateful to Ken Bamberger, David Barron, Lisa Bressman, Jake Gersen, Orin Kerr, Anne Joseph O'Connell, Todd Rakoff, Cass Sunstein, Alexander Volokh, and Judge Stephen Williams for helpful comments on earlier drafts.

T Assistant Professor, Harvard Law School.

$\$$ John H. Watson Professor of Law, Harvard Law School.

${ }^{1}$ No. 07-588, slip op. at 7 \& n.4 (U.S. Apr. 1, 2009).

${ }^{2} 467$ U.S. 837 (1984).

${ }^{3} \mathrm{We}$ are not the first to point out the difficulties of distinguishing between Chevron's two steps as well as between Chevron and other strands of judicial review doctrine. See, e.g., Sweet Home Chapter of Cmtys. for a Great Or. v. Babbitt, 30 F.3d 190, 193 (D.C. Cir. 1994), rev'd, 515 U.S. 687 (1995); Clark Byse, Judicial Review of Administrative Interpretation of Statutes: An Analysis of Chevron's Step Two, 2 Admin. L.J. 255, 256 n.10 (1988); Colloquy, Developments in Judicial Review with Emphasis on the Concepts of Standing and Deference to the Agency, 4 Admin. L.J. 113, 123-24, 126 (1990) (remarks of Hon. Stephen F. Williams) [hereinafter Williams]; Gary Lawson, Outcome, Procedure and Process: Agency Duties of Explanation for Legal Conclusions, 48 Rutgers L. Rev. 313, 338 (1996); Ronald M. Levin, The Anatomy of Chevron: Step Two Reconsidered, 72 Chi.-Kent L. Rev. 1253, 1260-61 (1997). Indeed, leading casebooks point out the difficulties of drawing these distinctions. See Stephen G. Breyer et al., Administrative Law and Regulatory Policy 327-29 (6th ed. 2006); Ronald A. Cass et al., Administrative Law 143-44 (5th ed. 2006); Peter L. Strauss et al., Gellhorn and Byse's Administrative Law 1034, 1036-40 (10th ed. 2003). These teaching materials, however, typically equivocate on whether these doctrinal distinc-
} 
two creates a conceptual problem, not merely a semantic one. The twostep structure causes material confusion among commentators and courts, with harmful consequences for administrative law doctrine and scholarship. Rather than trying to breathe life into each of Chevron's two steps, judges, scholars, and teachers of administrative law should jettison the two-step framework and acknowledge that Chevron calls for a single inquiry into the reasonableness of the agency's statutory interpretation. $^{4}$

\section{CHEVRON’s LOGIC, RIGHTLY UNDERSTOOD}

Under current doctrine, a court that reviews an agency's interpretation of a statute must address two questions (relevant here). The first question is whether the agency's construction of the statute is permissible on the merits, in light of the appropriate tools and principles of statutory interpretation. The second question is whether the agency's interpretive choice was the product of reasoned decisionmaking: even if the agency's interpretation is plausible as a construction of the statutory language, the agency's choice among plausible interpretations must not be "arbitrary [or] capricious." 5

Chevron divides the first inquiry-whether the agency's interpretation of the statute is valid - into two steps. At Step One, the court must ask whether, after "employing traditional tools of statutory construction," it is evident that "Congress has directly spoken to the precise

tions are ultimately sustainable, often suggesting that they are. We want to argue unambiguously that they are not.

${ }^{4}$ A semantic difficulty with our assertion that Chevron has only one step involves the question whether Chevron applies in the first place. Commentators sometimes say that Chevron has no fewer than three steps: the two steps recited in Chevron itself and an antecedent step at which courts decide whether Chevron or instead the older Skidmore analysis supplies the legal standard of deference. See United States v. Mead Corp., 533 U.S. 218, 226-27 (2001). This antecedent step is sometimes referred to as "Chevron Step Zero." See Cass R. Sunstein, Chevron Step Zero, 92 Va. L. Rev. 187 (2006). If one accepts that terminology, then our claim is that Chevron has two steps rather than three: Step Zero, plus the single step created by collapsing what courts currently describe as Steps One and Two. Alternatively, some prefer to describe the antecedent issue of whether Chevron applies at all as the question of "Chevron's Domain." See Thomas W. Merrill \& Kristin E. Hickman, Chevron's Domain, 89 Geo. L.J. 833 (2001). In that formulation, our thesis is that once a case falls within Chevron's domain, the Chevron analysis has only one step, rather than two. For simplicity, we use the latter formulation.

${ }^{5}$ Administrative Procedure Act, 5 U.S.C. $\$ 706(2)(A)(2006)$.

${ }^{6}$ Chevron, 467 U.S. at 843 n.9. 


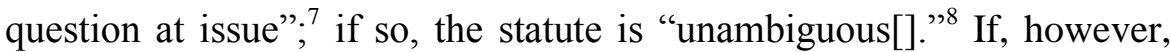
the court decides at Step One that the statute is ambiguous, the court proceeds to Step Two. At Step Two, the court must uphold the agency's interpretation so long as it is "based on a permissible construction of the statute." "Subsequent courts and commentators have treated Step Two as a requirement that the agency's statutory interpretation be "reasonable." If it is not, the court must reject it.

This structure artificially divides one inquiry into two steps. The single question is whether the agency's construction is permissible as a matter of statutory interpretation; the two Chevron steps both ask this question, just in different ways. As a result, the two steps are mutually convertible.

If an agency's construction of the statute is "contrary to clear congressional intent ... on the precise question at issue," 10 then the agency's construction is a fortiori not "based on a permissible construction of the statute." 11 Step One is therefore nothing more than a special case of Step Two, which implies that all Step One opinions could be written in the language of Step Two. ${ }^{12}$ Consider, as an example, FDA v. Brown \& Williamson Tobacco, in which the Supreme Court struck down the FDA's assertion of statutory jurisdiction over tobacco products. ${ }^{13}$ The Court reached this conclusion under Step One, asserting that Congress had expressed an intention on the "precise question" of whether the FDA could regulate tobacco. ${ }^{14}$ It would have been equally easy, however, for the Court to find under Step One that the full scope of the FDA's statutory jurisdiction is ambiguous - as it obviously is, given the numerous cases in which the courts of appeal have found ambiguity in the

\footnotetext{
${ }^{7}$ Id. at 842 .

${ }^{8}$ Id. at 843

${ }^{9} \mathrm{Id}$.

${ }^{10}$ Id. at 843 n.9.

${ }^{11} \mathrm{Id}$. at 843.

${ }^{12}$ See 1 Richard J. Pierce, Jr., Administrative Law Treatise 170-71 (4th ed. 2002); see also Levin, supra note 3, at 1282-83 (noting how judicial opinions that invalidate an agency's interpretation under Step Two could easily have been written as Step One opinions); Byse, supra note 3, at $256 \mathrm{n} .10$ ("[O]ne could, with considerable logic, conflate the two steps of Chevron into one . . . because if the intent of Congress is clear, a nonconforming interpretation would necessarily be unreasonable.").

${ }^{13} 529$ U.S. 120 (2000).

${ }^{14}$ Id. at $132-33$.
} 
same (or closely related) statutory language ${ }^{15}$ - but to declare that the FDA's assertion of jurisdiction over tobacco products was unreasonable under Chevron Step Two, for precisely the same reasons the Court advanced in the actual opinion.

Conversely, suppose the Court says that the statute is ambiguous at Step One but that the agency's interpretation is invalid at Step Two because it is not a permissible resolution of the ambiguity. This is analytically equivalent to saying that Congress did have an intention on the "precise question at issue"-if that question is framed not as "What does this statute mean?" but rather "Is the agency's interpretation within the permissible range of readings?" Congress' precise intention was to exclude the agency's interpretation from the permissible range. On this account, all Step Two opinions could be rewritten in the language of Step One. Consider, for example, Goldstein v. SEC, in which the D.C. Circuit struck down an SEC rule that regulated hedge funds under the Investment Advisors Act. ${ }^{16}$ The court apparently treated this as a Chevron Step Two case: the opinion acknowledged that the relevant statutory language was ambiguous but concluded that the SEC's rule was not consistent with any permissible reading of the statute. ${ }^{17}$ The court, however, could just as equally have resolved the case at Step One, framing the "precise question" as whether the Investment Advisors Act covers hedge funds and concluding that the answer was a clear "no."

Because Step One and Step Two opinions are always mutually convertible, Chevron has a unitary logic that requires only one step. ${ }^{18}$ The following diagram illustrates the point:

\footnotetext{
${ }^{15}$ See, e.g. Whitaker v. Thompson, 353 F.3d 947, 949-52 (D.C. Cir. 2004); Ala. Tissue Ctr. of Univ. of Ala. Health Serv. Found. v. Sullivan, 975 F.2d 373, 378 (7th Cir. 1992); E.R. Squibb \& Sons v. Bowen, 870 F.2d 678, 682-84 (D.C. Cir. 1989).

${ }^{16} 451$ F.3d 873 (D.C. Cir. 2006).

${ }^{17}$ Id. at $880-81$.

${ }^{18}$ See Williams, supra note 3, at 123-24, 126; see also Patricia M. Wald, Judicial Review in Midpassage: The Uneasy Partnership Between Courts and Agencies Plays On, 32 Tulsa L.J. 221, 243 (1996) (suggesting that whether a case is decided at Step One or Step Two depends on "how judges identify the precise question at issue, since at one level of generality the statute may answer it under Chevron step one, but at a more refined level there may be an ambiguity").
} 


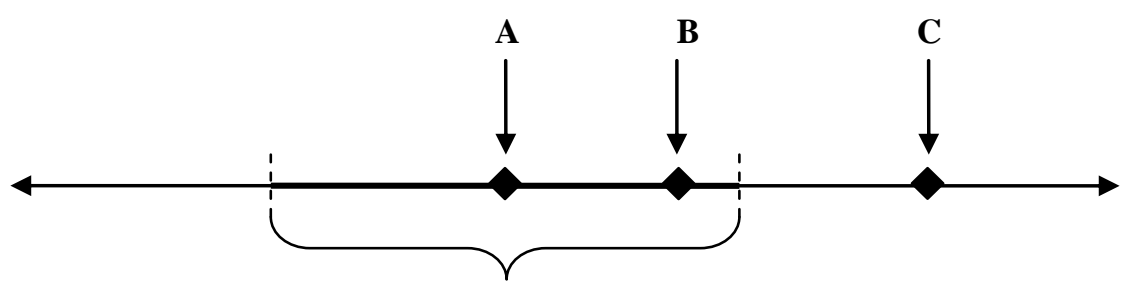

Range of Permissible Interpretations

("Zone of Ambiguity")

The diagram depicts the set of possible interpretations of a given statute as a one-dimensional space. The statutory language, read in light of the traditional tools of statutory construction, will suggest to the reviewing court both a "best" interpretation of the statute (interpretation " $\mathrm{A}$ " in the diagram) and a range of interpretations that are sufficiently plausible that the court would view them as reasonable, though not ideal. This range is the statute's "zone of ambiguity," the set of interpretations which the statute does not clearly prohibit. ${ }^{19}$ If the agency promulgates an interpretation within this zone (such as interpretation " $\mathrm{B}$ " in the diagram), then under Chevron the reviewing court must uphold the agency's interpretation, even though it differs from the court's mostpreferred construction (interpretation "A"). But if the agency chooses an interpretation outside the range of permissible meanings (such as interpretation " $\mathrm{C}$ " in the diagram), the court must strike it down.

In the latter case, where the court invalidates the agency's position at $\mathrm{C}$, one could say that the court decided the case at Step One, because the statute unambiguously prohibits the agency's interpretation. One could also say that the court decided the case at Step Two. On this rendition, the court pointed out, first, that the statute is "ambiguous" in the sense that the range of permissible interpretations contains more than a single element, but, second, that the agency's interpretation lies outside this

\footnotetext{
${ }^{19}$ The size of the zone need not be fixed by the statute itself; the amount of interpretive latitude the court gives the agency - the amount the court would permit the agency to deviate from the court's ideal reading - may depend in part on other factors, such as the court's confidence in the agency's expertise, its sympathy for the agency's policy goals, or its assessment of the importance of the interpretive issue. See Matthew C. Stephenson, The Strategic Substitution Effect: Textual Plausibility, Procedural Formality, and Judicial Review of Agency Statutory Interpretations, 120 Harv. L. Rev. 528, 547-48 (2006).
} 
range. Distinguishing between these approaches serves no useful purpose, since the nature of the analysis is identical in either case.

We might distinguish Step One and Step Two by interpreting Step One to ask whether Congress has clearly specified one, and only one, permissible interpretation of the statute. This approach assumes that a statute can unambiguously forbid an agency's interpretation only when Congress has specified a single possible meaning. But that assumption is false: Congress' intention may be ambiguous within a range, but not at all ambiguous as to interpretations outside that range, which are clearly forbidden. As E. Donald Elliott argues, Chevron's deep logic eliminates the classical idea that judges always can and should find a "point estimate" of statutory meaning. ${ }^{20}$ Rather, Chevron supposes that interpretation is an exercise in identifying the statute's range of reasonable interpretations, a range that opens up a "policy space" within which agencies may make reasoned choices ${ }^{21}$ — the "zone of ambiguity" depicted in our diagram.

There is therefore no good reason why we should decide whether the statute has only one possible reading before deciding simply whether the agency's interpretation falls into the range of permissible interpretations. After all, the case in which the statute has only one permissible interpretation is just a special case of the analysis described above. In our diagram, if Congress has been so clear that only one interpretation is possible, then the "zone of ambiguity" would consist of a single point (interpretation " $\mathrm{A}$ "), so of course any other interpretation (such as "B" or "C") would fall outside the permissible zone. But nothing of consequence turns on whether the set of permissible interpretations has one element or more than one element; the only question is whether the agency's interpretation is in that set or not.

\section{CHEVRON AND RATIONALITY REVIEW}

Some courts and commentators try to save Chevron's two-step inquiry by interpreting the content of the two steps differently. On this view, the question whether the agency's interpretation is permissible takes place entirely at Step One, while Step Two concerns the question whether the agency made its choice among permissible interpretations in

\footnotetext{
${ }^{20}$ See E. Donald Elliott, Chevron Matters: How the Chevron Doctrine Redefined the Roles of Congress, Courts and Agencies in Environmental Law, 16 Vill. Envtl. L.J. 1, 11 (2005)

${ }^{21}$ Id. at 12 .
} 
a reasonable manner. Indeed, this seems to be the preferred position of most of those who have considered seriously the apparent redundancy of Steps One and Two. ${ }^{22}$

The problem with this approach is that it renders Chevron Step Two redundant with standard State Farm-style ${ }^{23}$ hard look review under the "arbitrary and capricious" standard. ${ }^{24}$ After all, an agency's choice among permissible interpretations of a statutory provision is an exercise of policy discretion; Chevron itself is explicit about that point. ${ }^{25}$ As such, an agency's interpretive decision is subject to the ordinary strictures that attach to an agency's discretionary choice among policy alternatives: the decision must be based on a consideration of the relevant factors, and the agency must offer an explanation that is plausible and consistent with the evidence before it. ${ }^{26}$ A second Chevron step equivalent to the State Farm inquiry is therefore superfluous.

The two-step Chevron framework inevitably creates a redundancy; the only question is which redundancy it creates. On the one hand, if Step Two is about the plausibility of the agency's construction of the statute, then Step One and Step Two are redundant. On the other hand, if Step Two asks whether the agency's interpretation is the product of a

${ }^{22}$ See Nat'l Ass'n of Regulatory Util. Comm'rs v. ICC, 41 F.3d 721, 726-27 (D.C. Cir. 1994); Gen. Am. Transp. Corp. v. ICC, 872 F.2d 1048, 1053 (D.C. Cir. 1989); Pierce, supra note 12, at 172-74; Gary S. Lawson, Reconceptualizing Chevron and Discretion: A Comment on Levin and Rubin, 72 Chi.-Kent L. Rev. 1377, 1377-79 (1997); Levin, supra note 3, at 1276; Laurence H. Silberman, Chevron-The Intersection of Law \& Policy, 58 Geo. Wash. L. Rev. 821, 827-28 (1990). For a useful summary of D.C. Circuit opinions that have treated Chevron Step Two and hard look review as overlapping, see Levin, supra note 3, at 1263-66. Others, however, have criticized the attempt to collapse Step Two and hard look review. See e.g., Arent v. Shalala, 70 F.3d 610, 619-20 (D.C. Cir. 1995) (Wald, J., concurring); Continental Air Lines v. Dep't of Transp., 843 F.2d 1444, 1452 (D.C. Cir. 1988); Wald, supra note 18 , at 244 .

${ }^{23}$ Motor Vehicle Mfrs. Ass'n v. State Farm Mut. Auto. Ins. Co., 463 U.S. 29, 42-44 (1983).

${ }^{24}$ See Animal Legal Def. Fund v. Glickman, 204 F.3d 229, 234 (D.C. Cir. 2000) (noting this redundancy); Pierce, supra note 12 , at 172-74 (same).

${ }^{25}$ Chevron, 467 U.S. at 844-45, 864-66 ; see also Health Ins. Ass'n of Am. v. Shalala, 23 F.3d 412, 416 (D.C. Cir. 1994) (“'[R] eview of an agency's construction of an ambiguous statute is review of the agency's policy judgments.").

${ }^{26}$ State Farm, 463 U.S. at 42-44; see also Lawson, supra note 3, at 326 ("“A]n agency can satisfy the Chevron test and still lose the case ... if the agency reaches its interpretation through a decisionmaking process that is 'arbitrary' or 'capricious' ...."); cf. Nat'l Cable \& Telecomms. Ass'n v. Brand X Internet Servs., 545 U.S. 967, 981 (2005) (stating that although interpretive inconsistency is irrelevant to the Chevron inquiry, if this inconsistency is not adequately explained it might render the agency's interpretation arbitrary and capricious under State Farm). 
reasoned decisionmaking process, then Step Two is redundant with State Farm. We have the doctrinal equivalent of musical chairs, with three doctrines (Chevron Step One, Chevron Step Two, State Farm) and only two chairs (interpretive reasonableness and reasoned decisionmaking). The question, therefore, is which doctrinal distinction should be collapsed and which preserved?

Contrary to the views of most of the other scholars who have considered this issue ${ }^{27}$ we believe that conflating Chevron Step Two's "reasonableness" analysis with State Farm's reasoned decisionmaking analysis is more confusing than our suggestion, which is simply to collapse Chevron's two current steps into one. Our proposed revision would clarify the doctrine while keeping the interpretive question and the "reasoned decisionmaking" question analytically separate. Trying to save Chevron's two steps by reading one of them as equivalent to arbitrary and capricious review serves no useful purpose and creates additional problems, as we will discuss shortly. ${ }^{28}$

\footnotetext{
${ }^{27}$ See Lawson, supra note 22. Gary Lawson initially took the position that Chevron's two steps should simply be collapsed into one inquiry, but he was subsequently persuaded by Ronald Levin's analysis that Chevron Step Two should be read as coterminous with State Farm-style hard look review. Compare Lawson, supra note 3, at 340 (1996) ("[S]ubstantive reasonableness under Chevron step two should be judged solely by reference to the organic statute under consideration, while substantive reasonableness under the arbitrary or capricious test can be judged by anything that is generally relevant to reasoned decisionmaking."), with Lawson, supra note 22, at 1377-80 (1997) (noting that in contrast to Professor Lawson's own earlier argument, "Professor Levin would convert step one into an all-thingsconsidered assessment of the substantive reasonableness of the agency's interpretation and make step two a straightforward application of arbitrary or capricious review," concluding that this analysis is "almost certainly right," and declaring, "Sign me up"). We think Professor Lawson had it right the first time around.

${ }^{28}$ Professor Levin — one of the principal advocates of reconceptualizing Step Two as nothing more than standard arbitrary and capricious review-has indicated that he takes this position in part because it "is too late in the day to simply abrogate the second step as excess baggage; the prestige of the Chevron formula makes such a development unlikely." Levin, supra note 3, at 1296. It seems (though this is not entirely clear) that Professor Levin may share our view that simply eliminating the distinction between Step One and Step Two would be the best and clearest solution to the doctrinal overlap. We tend to agree with Professor Levin that if this turns out to be impossible, explicitly collapsing Step Two and State Farm is better than continuing to suggest some special, independent role for each of Chevron's two steps. We differ from Professor Levin only insofar as we do not believe Chevron's two-step structure is so sacrosanct that it must now be accommodated. In our view, it takes no more intellectual work, and no more disruption of existing doctrine, to collapse Steps One and Two than it does to collapse Step Two and State Farm.
} 


\section{THE CONSEQUENCES OF CONFUSION}

Perhaps the consequences of Chevron's misleading two-step structure are not severe. After all, despite the regular, almost ritualistic, invocation of the Chevron two-step, most courts seem to have a clear understanding of the two relevant questions-Is the agency's construction permissible? Was it the product of a reasoned decisionmaking process? - and they manage to address these questions without tripping over the superfluity of one or the other of Chevron's two steps. A model opinion, in this respect anyway, is the Supreme Court's recent Global Crossing decision, in which the Court upheld an agency regulation by simply concluding that the agency's interpretation was "reasonable [and] hence . . . lawful," ${ }^{29}$ without reciting the Chevron two-step test in the talismanic fashion of so many lower courts. A substantial number of court of appeals decisions also collapse the Chevron analysis into a single inquiry, without much obvious effect on the bottom-line question of whether the agency's interpretation is upheld. ${ }^{30}$ Nonetheless, we believe that the confusion engendered by Chevron's artificial division of one inquiry into two steps has adverse consequences for administrative law doctrine and scholarship.

First, insofar as judges believe that Step One requires them to ascertain whether the statute has a single, clear meaning before deciding whether the agency's interpretation is reasonable, the two-step structure may actually undermine some of the values that Chevron deference is supposed to advance. For one thing, if judges spend an inordinate amount of time trying to figure out the best construction of the statute, it may be difficult for them to shift mental gears to decide whether an agency interpretation that differs from the judge's sense of the best interpretation is nonetheless reasonable. ${ }^{31}$ For another, the more judges are

\footnotetext{
${ }^{29}$ Global Crossing Telecomms. v. Metrophones Telecomms., 550 U.S. 45, 47-48 (2007).

${ }^{30}$ See Orin S. Kerr, Shedding Light on Chevron: An Empirical Study of the Chevron Doctrine in the U.S. Courts of Appeals, 15 Yale J. on Reg. 1, 30 (1998) (finding, in a sample of over 200 court of appeals cases decided in 1995-1996, that the courts applying Chevron "condensed the two-step test into a single question of whether the interpretation was 'reasonable' in $28 \%$ of the applications"); id. at 31 (finding that courts that collapsed Chevron into one step upheld the agency interpretation $78 \%$ of the time, while those courts that preserved the two-step framework upheld the agency interpretation $71 \%$ of the time).

${ }^{31}$ It is not clear whether this is in fact a problem, and if it is, how large a problem it may be. For discussion, compare Jacob E. Gersen \& Adrian Vermeule, Chevron as a Voting Rule, 116 Yale L.J. 676, 693-98 (2007) (suggesting that this psychological claim is plausible), with Matthew C. Stephenson, The Costs of Voting Rule Chevron: A Comment on Gersen
} 
inclined to declare that a statute has one and only one meaning, the harder it will be for future agencies to adopt alternative constructions of the same statute that the initial court did not anticipate. ${ }^{32}$

Second, if judges interpret Step Two as imposing a "reasoned decisionmaking" requirement that strongly resembles State Farm, as many commentators have advocated, the result may be an unjustified departure from the standard approach to hard look review in the statutory interpretation context. Courts may mistakenly conclude that they must always resolve the question of interpretive plausibility before addressing the issue of reasoned decisionmaking, because the former is part of Step One and the latter is part of Step Two. Yet there are cases in which the agency has clearly failed the reasoned decisionmaking requirement, while the interpretive question is close. It is pointless to require courts to proceed to the reasoned decisionmaking question only after answering the interpretive question, and because neither question goes to the court's jurisdiction, there is no legal obligation to do so. More generally, separating the "reasoned decisionmaking" requirement into two separate inquiries-Chevron Step Two and State Farm hard look review-invites courts to assume that arbitrary and capricious review is more rigorous, or less rigorous, or just somehow different in the context of statutory interpretation than in other domains where agencies make discretionary policy choices. ${ }^{33}$ But there is no obvious reason why this should be so.

and Vermeule's Proposal, 116 Yale L.J. Pocket Part 238, 239-42 (2007), available at http://yalelawjournal.org/images/pdfs/99.pdf (expressing doubts).

${ }^{32}$ See Nat'l Cable \& Telecomms. Ass'n v. Brand X Internet Servs., 545 U.S. 967, 982-85 (2005). The decision whether or not to collapse Chevron's two steps has no effect whatsoever on the question whether a prior judicial construction of a statute in a non-Chevron case will preclude an agency from later adopting a different interpretation (the issue with which the Brand $X$ case was principally concerned). Under Brand $X$, a prior judicial construction binds the agency only if the earlier court's holding clearly indicated that the alternative interpretation now favored by the agency was unambiguously forbidden. Id. Under our framework, Brand $X$ operates exactly the same way: if the prior court stated clearly that the agency's (current) interpretation was outside the zone of the permissible, then the agency may not now adopt that interpretation. Here too, nothing in the logical structure of the inquiry requires a distinction between cases in which the zone of the permissible reduces to a single point, and cases in which it does not-the distinction at the heart of the current two-step framework.

${ }^{33}$ See Cont'l Air Lines v. Dep't of Transp., 843 F.2d 1444, 1452 (D.C. Cir. 1988) (insisting that Chevron Step Two involves a fundamentally different sort of "reasonableness" inquiry than standard hard look review, such that the latter body of doctrine cannot be applied wholesale in the statutory interpretation context); Lawson, supra note 3, at 341 ("[T] he standard of review for agency outcomes under the arbitrary or capricious test may be more deferential than the standard of review under Chevron step two."); Wald, supra note 18, at 244 
Third, the artificial division between Chevron's two "steps" muddies the relationship between Chevron deference and other tools of statutory interpretation, such as canons of construction, legislative history, and purposive analysis. The relationship between Chevron and these other interpretive tools raises a host of difficult and important issues, yet judges and scholars are sometimes distracted by the question whether this or that interpretive tool ought to come into play at Step One or Step Two, instead of focusing on the real questions. Consider, for example, the Ninth Circuit's recent en banc decision in Morales-Izquierdo v. Gonzales, in which Judge Kozinski's majority opinion and Judge Thomas's dissent debated the appropriate relationship between Chevron deference and the constitutional avoidance canon. ${ }^{34}$ Both opinions unhelpfully

(arguing that failing to recognize the distinction between Chevron and hard look review will lead courts to be too aggressive in reviewing agency interpretations); Williams, supra note 3, at 123-24, 126 (hypothesizing that Chevron's two-step structure creates the misleading impression that rationality review in the statutory interpretation context is less demanding than in other contexts). It is important here to distinguish those considerations that determine the bounds of the zone of ambiguity - the application of the traditional tools of statutory construction - from those considerations that bear on the reasonableness of the agency's selection of one interpretation rather than another (assuming, perhaps provisionally, that the agency's interpretation falls within the zone of ambiguity). The former set of considerations may be unique to statutory interpretation. The latter set, however, are no different in kind from those that would be applied to any discretionary agency policy choice.

There may still be a tricky doctrinal classification problem for those rare cases when an agency's only (or principal) explanation for its interpretative choice is its legal conclusion that this choice is required by the statute (that is, the agency has no lawful discretion to do anything else). Assuming that the agency's interpretation is permissible under Chevron, the reviewing court would have to decide whether the agency's reason for selecting this particular interpretation (that it is required by the statute) is adequate under State Farm. In this limited class of cases, then, a reviewing court may have to address the question whether the statute is ambiguous (that is, whether the zone of ambiguity contains more than one element) separately from the question whether the agency's interpretation is within that zone. But we do not find this especially troubling. As in all other State Farm cases, the reviewing court would decide whether the agency's explanation for its decision is arbitrary and capricious. As long as the agency's arguments as to why its interpretive choice is legally required are reasonable (that is, non-arbitrary), the agency should prevail under State Farm. If, however, the court concludes that the agency's claims of legal constraint are not reasonable-if, for example, the statute obviously permits more than one interpretation, or a challenger made timely comments to that effect which the agency did not adequately address - then the agency should lose under State Farm.

${ }^{34} 486$ F.3d 484, 492-93 (9th Cir. 2007) (en banc); id. at 504 (Thomas, J., dissenting). The constitutional avoidance canon instructs courts to avoid interpreting statutes in ways that raise serious constitutional questions when a reasonable alternative interpretation is available. See Edward J. DeBartolo Corp. v. Fla. Gulf Coast Bldg. \& Constr. Trades Council, 485 U.S. 568, 575 (1988); NLRB v. Catholic Bishop of Chi., 440 U.S. 490, 499-501 (1979). 
framed this difficult problem in terms of whether the avoidance canon is relevant at Step One or not. The shared assumption seemed to be that if it is (Judge Thomas's position), ${ }^{35}$ then the canon takes precedence over Chevron deference, while if it is not (Judge Kozinski's position), ${ }^{36}$ the canon is irrelevant in a Chevron case. Yet because Chevron's two steps are mutually convertible, deciding whether the constitutional avoidance canon applies at Step One or at Step Two cannot do any meaningful analytical work. If the canon is relevant at Step One, the court must still decide whether or not the canon renders an otherwise reasonable agency interpretation clearly contrary to the statute's meaning. If the canon is relegated to the (allegedly distinct) Step Two, the court must still decide whether the canon renders an otherwise plausible agency interpretation unreasonable. The ultimate substantive question is identical in either case, so the classification question-Does the avoidance canon come into play at Step One or Step Two? - is meaningless.

Kenneth Bamberger has recently argued that normative canons of statutory interpretation, including the constitutional avoidance canon, should be treated "contextually" rather than "categorically," and that courts deciding whether to use such canons to override agency interpretations should therefore invoke these canons at Step Two rather than at Step One. ${ }^{37}$ A great deal may turn on whether the relationship between Chevron and various canons of construction is governed by a rule-like hierarchy of interpretive principles or by a more standard-like contextual inquiry. But nothing at all turns on whether normative canons are brought into the interpretive inquiry at Step One or Step Two, because the two steps are mutually convertible. If, in context, judges find that normative canons imply a sufficiently powerful actual or constructive congressional intention to render the agency's interpretation impermissible, then this conclusion can be written in either the terms of Step One (an intention on the precise issue) or in terms of Step Two (an impermissible reading of statutory ambiguity). ${ }^{38}$ A unitary Chevron inquiry can accommodate any degree of context-specificity that is thought desirable, and conflating the question whether the relationship between Che-

\footnotetext{
${ }^{35}$ Morales-Izquierdo, 486 F.3d, at 504 (Thomas, J., dissenting).

${ }^{36}$ Id. at $492-93$.

${ }^{37}$ Kenneth A. Bamberger, Normative Canons in the Review of Administrative Policymaking, 118 Yale L.J. 64, 66-69 (2008).

${ }^{38}$ See Levin, supra note 3, at 1280 (arguing that there is "no evident reason" why Chevron's two-step framework should affect the debate over the use of canons of construction).
} 
vron and normative canons should be governed by rules or standards with an artificial choice between applying those canons at Step One or Step Two, obscures the more important substantive and methodological questions at stake.

\section{CONCLUSION}

Sometimes judges write watershed opinions whose deep logic only gradually becomes clear and whose language fails to capture that deep logic. In such cases, there is no need for courts and scholars to cling to the original language of the opinions, at least where abandoning the original language would clarify matters without loss of content. Chevron is a case of this sort. Judges and scholars could simplify matters, at no collateral cost, by recognizing that Chevron, notwithstanding the language of the opinion itself and decades of subsequent exegesis, has only one step. 